\title{
POLÍTICA CULTURAL E O ESTADO A dinâmica institucional na produção da cultura regional
}

\author{
Marcela Guimarães Silva \\ Universidade Federal do Pampa, Brasil \\ Tiago Costa Martins \\ Universidade Federal do Pampa, Brasil
}

\begin{abstract}
Resumo: A proposta desse estudo é compreender a dinâmica institucional do Estado a partir das políticas empreendidas no campo cultural. Para isso, o mesmo se pauta pela configuração da região das Missões jesuítas-guaranis, sul do Brasil, para posteriormente apontar algumas atribuições institucionais na produção da cultura regional. Aborda noções de produção cultural, políticas e instituições culturais e em seguida toma como elementos históricos os domínios do patrimônio e da música e a atuação do Governo de Getúlio Vargas nos períodos em que presidiu o país. Através de pesquisas bibliográficas e documentais o artigo debate as políticas culturais como ações empreendidas pelo Estado em contraponto às práticas da população regional. Conclusivamente são destacadas cinco atribuições institucionais do Estado: regulação, normatização, cognição, gestão e mediação. Tais atribuições tanto podem ser vistas de maneira articulada como isoladas no contexto investigado, sendo que em ambas as condições vêm a contribuir para as pesquisas e as práticas culturais.
\end{abstract}

Palavras-chave: Atribuições Institucionais; Práticas Culturais; Missões Jesuíticas-Guaranis - Brasil.

\section{Introdução}

A partir da segunda metade do século XX o uso e a conceituação de cultura foram ampliados na dinâmica social. Cultura passou a sintetizar o compartilhamento de significados comuns, das produções simbólicas e materiais das sociedades, em permanente elaboração e reconfiguração. Cultura vista como atividade "ordinária" (Willians, 1981), envolvendo desde as práticas sociais do cotidiano, a macroorganização política e econômica, a produção científica, artística e cultural. "A cultura é uma produção. Tem sua matéria-prima, seus recursos, seu ‘trabalho produtivo'. Depende de um conhecimento da tradição enquanto 'o mesmo em mutação' e de um conjunto efetivo de genealogias" (Hall, 2003: 44).

Nessa ordem é possível dizer que a produção cultural pressupõe momentos específicos. 
Em sentido lato tem-se a produção, a circulação/distribuição e o consumo/recepção. Além disso, o conjunto de genealogias está associado à constituição de cada produção cultural dentro de uma organização de agentes, meios de produção, canais de distribuição, públicos e instâncias institucionais.

Instituições como o Estado, o Mercado e o Terceiro Setor apresentam características e atribuições específicas em cada momento da produção e em cada domínio cultural (patrimônio, artes visuais, etc.). A proposta desse estudo é compreender as atribuições das instituições na produção da cultura, especialmente aquelas ligadas ao Estado. Inicialmente apresenta-se uma noção de produção cultural e seus momentos. Na segunda parte, os aspectos genéricos que definem as instituições. Por fim, discorre-se uma reflexão sobre as instituições culturais, procurando compreender suas atribuições na produção cultural a partir do contexto da região Missões jesuítas-guaranis, localizada no sul Brasil considerando como elementos históricos os domínios do patrimônio e da música e a atuação do Governo de Getúlio Vargas.

\section{Produção cultural}

A partir do surgimento e da expansão dos meios de comunicação de massa, a dimensão da cultura inseriu-se numa dinâmica peculiar. Nota-se que a expansão do capitalismo e da industrialização provocou a "absorção" da cultura nessa mesma lógica: Cultura como uma mercadoria de lazer e entretenimento, diversão e distração dentro de um processo material vinculado às formas materiais de reprodução da vida social (Horkheimer \& Adorno, 2000).

Dentro de uma ordem material não existe "produção de sentido que não esteja inserida em estruturas materiais. Qualquer prática é simultaneamente econômica e simbólica, uma vez que agimos através dela, construímos uma representação que lhe atribui um significado" (Canclini, 1983: 29-30). Nesse contexto estrutural há uma relação estabelecida dentro do processo de criação (autor-obra-intermediário-público) e a sociedade; uma associação entre material e simbólico dentro da definição de produção 
cultural por meio dos meios de produção e as relações sociais de produção (Canclini, 1979).

O jogo de relações e representações que abarcam todo este processo confere o caráter específico da produção cultural e configura um ciclo produtivo de produção, circulação e recepção/consumo. No campo da cultura e da dinâmica contemporânea, pela ordem capitalista e suas consequências, é possível estabelecer um ciclo cultural (Unesco, 2009) formado por: criação de ideias, conteúdos e produtos originais (o artista e a obra); produção das formas culturais (como uma telenovela), bem como as ferramentas, a estrutura e os processos de fabricação (impressão de livros, por exemplo); difusão com o intuito de dar visibilidade e alcançar consumidores/plateia/público; exibição/transmissão dentro do contexto, do lugar e da atividade cultural (TV, teatro, museus, etc.); e consumo/participação na prática da atividade cultural em si realizada pelo consumidor, plateia, etc.

A produção cultural está associada a um conjunto de ações, expressões e objetos carregados de significados. Uma gama de manifestações verbais, símbolos, textos e artefatos. Indivíduos que se expressam e que procuram entender a si mesmo e aos demais pela interpretação desses artefatos. Expressões que produzem e recebem (Thompson, 1995).

Nesse contexto há uma organização estabelecida dentro dos domínios culturais, formado por bens, serviços e atividades de uma determinada produção cultural. O "Marco de Estatísticas Culturais" da UNESCO (2009) apresenta seis domínios culturais centrais: Patrimônio Cultural e Natural; Apresentações artísticas e celebrações; Artes visuais e artesanato; Livros e produtos impresso; Meios audiovisuais e interativos e; Desenho e serviços criativos.

As atividades, bens e serviços constitutivos dos domínios envolvem processos industriais ou não. Por outro lado, envolvem valores estéticos, simbólicos e espirituais em diferentes proporções e conexões com as estruturas materiais. Desta forma é 
possível contextualizar o ciclo da produção cultural dentro de um processo circunscrito pelos recursos materiais e procedimentos para a produção e pelas relações sociais de produção entre criador, intermediários, instituições (públicas e privadas), organizadores, público, etc. tal como sugere Canclini (1979).

\section{Políticas culturais}

Historicamente as políticas culturais estão posicionadas numa visão estatista na qual a sua configuração e primazia estariam na ação do Estado. A partir da década de 1960 surgiram as primeiras discussões conceituais e, até mesmo, normativas do que seria política cultural. Frisa-se, especialmente, a atuação da UNESCO que em 1969 apresenta um conceito aos países-membros da ONU, no qual entende política cultural "como um conjunto de princípios operacionais, práticas administrativas e orçamentárias e os procedimentos que fornecem uma base para a ação cultural do Estado.” (Unesco, apud Reis, 2011: 02).

Essa abordagem destaca a personalidade jurídica como determinante da ideia "pública”, ou seja, se é uma diretriz elaborada por um ente do Estado, então ela é uma política pública. Por outro lado, confere uma racionalidade técnica e operacional na prática estatal à cultura. A visão instrumental da UNESCO procura potencializar a cultura por meio da otimização dos recursos materiais e humanos, conferindo importância aos processos internos de formulação e implementação na gestão pública da cultura. Além disso, dentro do protagonismo do Estado não descarta que a falta de ação também é uma política cultural. Portanto, a ausência de ações, saliente na história das políticas culturais no Brasil, deve ser vista como uma política cultural.

O debate sobre a prática e o conceito de política cultural é reconfigurado dentro da visão multicêntrica ou policêntrica das políticas públicas. Fundamentalmente essa abordagem revê a compreensão do que é "pública". O que a descreve são os contornos da definição do problema "e não se o tomador de decisão tem personalidade jurídica estatal ou não estatal" (Secchi, 2013: 05). 
A abordagem multicêntrica das políticas culturais ao enfatizar o problema como sendo público por conta do fim coletivo - população - enfatiza a presença de outros agentes que não somente o estatal: organizações privadas, organizações não governamentais, organismos multilaterais, redes de políticas públicas, etc. Considera-se, assim, que inúmeros agentes e instituições poderão fazer políticas culturais. Mas a despeito desse "fazer" é preciso retomar a constituição simbólica na qual as políticas culturais contemplam propor a satisfação das necessidades da população.

Parte-se aqui da retomada da condição onde a produção cultural é caracterizada como a (i) produção de significados e (ii) está inserida num contexto estruturado. A produção de significado localiza-se nas práticas cotidianas das pessoas, através das relações estabelecidas com os objetos e os demais indivíduos. Nesta construção social se estabelecem províncias finitas de significados. Noutro ponto $-\mathrm{o}$ do contexto estruturado - tem-se a estrutura social que condiciona e articula os significados sociais num cenário mais amplo do sistema social. Este sistema, constituído por um conjunto complexo de atividades, funções, órgãos e subsistemas com determinadas especializações, vai dispor a esfera da produção simbólica dentro de um contexto permeado de agentes e instituições dispostos a manter ou afirmar determinados significados sociais.

É nessa conjuntura que se expõe o microambiente e a macroestrutura na vida social, tema discutido na abordagem teórica do estudo, principalmente ao servir de condição na relação indivíduo e estrutura como parâmetro às políticas culturais. Em especial, esta dimensão sociológica da vida - contexto estruturado - é que define as políticas culturais como uma intencionalidade explícita de construção de sentido, através de meios adequados e de fins (diretrizes) previamente definidos. Por isso se confere às políticas culturais um raio de ação estabelecido no âmbito macrossocial, público e institucional da cultura. Proposta apresentada por Brunner (1992: 211) ao dizer que as políticas culturais são 
intentos de intervención deliberada, con los medios apropiados, en la esfera de constitución pública, macrosocial e institucional de la cultura, con el fin de obtener efectos buscados. Son, por lo general, formas de intervención que tienden a operar sobre el nivel organizacional de la cultura; preparación y carrera de los agentes, distribución y organización de los medios, renovación de los medios, formas institucionales de la producción y circulación de biens simbólicos, etcétera.

Por um lado este conceito apresenta as políticas culturais posicionadas em algum momento da produção cultural, configurando as diretrizes de intervenção focadas na criação cultural; na elaboração da preservação do patrimônio; no consumo cultural; dentre outras. Assim, é preciso considerar nas políticas do setor os espaços sociais de afirmação cultural e a relação com os domínios culturais em seus diferentes momentos. Diante das discussões apresentadas até o momento, o conceito de política cultural pode ser resumidamente entendido como uma ação de intervenção, incluso a ausência desta, estabelecida dentro de uma configuração de agentes e instituições que operam nos diferentes momentos da produção cultural, buscando satisfazer as necessidades culturais e a manutenção ou a transformação da ordem social no campo simbólico.

\section{Instituições culturais do Estado}

Genericamente instituição pode ser entendida como um sistema organizado e complexo de relações sociais que possuem certa permanência e que incorpora valores e procedimentos comuns, a qual responde a certos anseios sociais (Dias, 2010).

Scott (2008) entende que as instituições são atividades que dão estabilidade e sentido ao comportamento social, e são difundidas pelas culturas, estruturas e rotinas sociais em múltiplos níveis de jurisdição, constituídas por uma dinâmica estrutural reguladora, normativa e cognitiva. A regulação estabelece e regula o comportamento e as práticas sociais; está em jogo a capacidade de estabelecer regras, fiscalizar a conformidade destas e manipular sanções - recompensas ou punições (Scott, 2008). A normatização sugere uma condição prescritiva, avaliativa e, muitas vezes, obrigatória na vida social. 
Scott (2008) sugere que as questões normativas estão contidas em sistemas de valores e normas e é nesse conjunto que se definem metas e/ou objetivos, assim como as formas adequadas para persegui-los. Por fim, a cognição compreende a constituição da realidade social dentro das concepções comuns e da construção dos significados num quadro comum de referência. Os elementos culturais são vistos como constitutivos e, ao mesmo tempo, como constituídos no ambiente institucional.

Já as instituições culturais do Estado estão contidas dentro de um conjunto de propostas de intervenção na realidade social. Tratam-se de políticas culturais que no entender de Canclini (1987) são um conjunto de intervenções realizadas pelo Estado, as instituições civis e os grupos comunitários organizados. $\mathrm{Na}$ mesma linha de pensamento, Brunner (1987: 178) entende que as políticas culturais possuem como terreno e objetivo "la combinación típica de agentes y de instancias institucionales de organización" que formarão a matriz básica dos circuitos (ou ciclos) culturais. Ou seja, as políticas culturais atuam nos circuitos culturais, sendo que tais ciclos combinam uma série de agentes e instâncias institucionais que abarcam e estão contidos nas diferentes fases de produção, circulação e consumo dos bens culturais. Dentro da produção cultural os mecanismos institucionais do Estado estão direcionados à produção, circulação e distribuição (Brunner, 1987). Nesse sentido, a organização e o controle seriam instituídos formalmente. As instituições culturais do Estado respondem, a priori, pela intervenção pública ou coletiva. Mas é importante indagar qual o papel do Estado nesse contexto? Há de se ter em conta a relação estrutural baseada no governo e na sociedade.

No que tange ao Estado, Brunner apresenta os motivos, objetivos e formas de intervenção das ações praticadas a partir de Heiskanen (1982) e Girard (1982). Os motivos estão na ordem da promoção, proteção e controle, com destaque para a subvenção. Ou seja, fornecer subsídios públicos para domínios fracos economicamente, mas culturalmente importantes. Além disso, destacam-se a proteção da produção cultural territorial e dos direitos da propriedade intelectual e o controle de 
ramos/atividades estratégicos para o interesse do Estado e da sociedade, dentre outros.

A conexão com tais motivos sugere alguns tipos de objetivos cujas intervenções públicas procuram alcançar, intervindo na produção cultural. Destacam-se: ampliação do acesso à cultura por meio de ações de democratização e descentralização; promoção da qualidade dos meios de comunicação de massa; promoção do trabalho criativo e das condições de trabalho dos artistas (criadores); modernização das instituições culturais; potencialização da produção cultural nacional (territorial, nas questões de escala); proteção da autonomia cultural do país (território) em relação ao exterior (Brunner, 1987).

A forma de atuação do Estado é apresentada por meio de seis práticas institucionalizadas: apoio direto, quando o Estado compra bens ou serviços culturais; apoio indireto, através de políticas tributárias - leis de renúncia fiscal; regulações, como para os acessos a bens e serviços culturais; incentivo, quando fomenta atividades com premiações, festivais, etc.; convenções internacionais, como os acordos multilaterais; e políticas financeiras à indústria cultural, como créditos bancários e apoio a exportação, por exemplo.

\section{Políticas culturais e a região}

O relato de algumas políticas culturais procuram descrever as práticas intervencionistas realizadas na região das Missões no sul do Brasil, com ênfase nos

munícipios de São Miguel das Missões, São Luiz Gonzaga e Santo Ângelo. Assim, inicialmente apresenta-se algumas políticas culturais empreendidas pelo Estado. Na sequência destaca-se a ação do mercado e da sociedade civil, também no âmbito das políticas culturais. Começa-se, assim, com a questão do Estado.

\section{a. Estado e patrimônio}

$\mathrm{O}$ que se considera como contemporaneidade está associado ao século XX. Intencionalmente se quer estabelecer relações com o Governo de Getúlio Vargas e a consolidação e atuação da Secretaria do Patrimônio Histórico e Artístico Nacional. 
A década de 1930 no Brasil foi marcada por um processo de rupturas e grandes transformações sociais: o fim da política “café com leite” (São Paulo - Minas Gerais), a industrialização e urbanização e as conquistas trabalhistas, dentre outras. No campo cultural foi uma década reconhecida como o período de institucionalização da cultura. O governo de Getúlio Vargas sistematizou e executou ações no campo do desenvolvimento simbólico dentro de uma perspectiva estratégica ${ }^{1}$. Nesses moldes o patrimônio foi visto como um elemento formador da identidade nacional.

A Constituição de 1937, promulgada no Estado Novo, logo no segundo artigo, passou a permitir apenas uma bandeira, um hino e um brasão abolindo, assim, os símbolos estaduais. Segundo Getúlio Vargas, eles haviam merecido demasiada devoção em detrimento de um sentimento de brasilidade. (Meira, 2008: 131).

Nota-se a intenção de fazer do Estado um ente mais presente na vida dos cidadãos. A partir da criação do Ministério da Saúde e Educação e da efetivação do ministro Gustavo Capanema (1934 até 1945), foram criadas inúmeras instituições culturais como o Instituto Nacional do Livro, o Serviço Nacional de Teatro e o Serviço do Patrimônio Histórico e Artístico Nacional (SPHAN), todos em 1937. A criação dessas institucionalidades está dentro de um "processo de legalização, institucionalização e sistematização da presença do Estado na vida política e cultural do país" (Falcão, 1984: 26). Mas, mais do que isso, a conjuntura do Brasil à época é marcada pela relação regional x nacional. A partir do Estado Novo o Brasil passou a ter um poder cada vez mais deslocado do âmbito regional para o nacional. Em grande medida, essas institucionalidades vão referendar a centralidade do Estado e do poder central no campo da cultura.

Nesse contexto, o SPHAN surge com o propósito de promover o tombamento, a conservação, o enriquecimento e o conhecimento do patrimônio nacional (Calabre, 2009). Havia em sua criação os desafios de chamar a atenção e fomentar a participação

${ }^{1}$ O primeiro momento do governo Vargas corresponde aos períodos de 1930 a 1934 (Chefe do Governo Provisório), de 1934 a 1937 (Constitucional) e de 1937 a 1945 (Estado Novo). O segundo corresponde a sua reeleição (1951 a 1954). 
da população no campo da preservação cultural. Além disso, no campo do desenvolvimento simbólico, buscava-se a unificação da ideia de patrimônio "brasileiro" mais do que regional. No primeiro caso o mecanismo de tombamento representou um elemento de normatização e legitimação da intervenção do Estado. Já no desenvolvimento simbólico, no início da atuação do SPHAN, a política se configurou apenas na preservação arquitetônica como elemento cognitivo, sendo que a origem social dos monumentos tombados indicava tratar de monumentos vinculados às conquistas da etnia branca; da religião católica; do Estado; e da elite política e econômica do país. (Falcão, 1984).

Essa é a configuração inicial do SPHAN, que teve como diretor responsável Rodrigo Melo Franco de Andrade desde a sua fundação até 1967, quando foram criadas divisões regionais pelo Brasil e que no Rio Grande do Sul teve a atuação de Augusto Meyer (Calabre, 2009: 25). Inserido nesse contexto está a região das Missões, especialmente as ruínas da igreja jesuítica-missioneira de São Miguel (naquele período distrito de Santo Ângelo). O estudo referencial de Meira (2008) atesta que a atuação do SPHAN nas Missões teve protagonismo no reconhecimento das ruínas como elemento cultural brasileiro. Em 1937, Rodrigo Melo procura Augusto Meyer para solicitar ajuda no levantamento dos bens arquitetônicos do Rio Grande do Sul e, segundo ele, o estado estava fisicamente longe da ação do SPHAN. O levantamento de documentos (fotos, históricos, etc.) representou a primeira ação institucional no Rio Grande do Sul.

A política de preservação iniciada pelo SPHAN está diretamente associada aos elementos cognitivos de reconhecimento de tais patrimônios. São Miguel foi um exemplo fundamental para compreender os valores que estavam sendo construídos pela incipiente instituição. Meira (2008) aponta uma referência aos valores históricos e artísticos e o processo contraditório com a qual as ruínas passam a ser vistas e legitimadas pela política empreendida.

É interessante que os dois marcos históricos definidos por Meyer para balizar o 
inventário do patrimônio no Estado - as Missões Jesuítico-Guarani e a Revolução Farroupilha - estavam relacionados a controvérsias historiográficas na época. Com relação às primeiras, eram questionadas pela historiografia gaúcha de matriz lusa, que começara a manifestar-se na década de 1920 e se aprofundara a partir de 1930, segundo Gutfreind. O reconhecimento das ruínas de São Miguel Arcanjo com o patrimônio nacional não era contraditório com essa vertente historiográfica, uma vez que o relatório de Lucio Costa concordava que se tratava de um monumento espanhol (Meira, 2008: 226).

O debate estabelecido em torno dessa contradição está pautado pelo reconhecimento histórico ou artístico das ruínas para a cultura do Brasil. Sobre o primeiro os relatos sempre posicionam as Missões como elemento jesuítico, desconsiderando os índios guaranis do processo. Nos demais patrimônios do Rio Grande do Sul o critério era histórico, mas Missões o elemento missioneiro era considerado pelo valor artístico. Quando da realização do levantamento do patrimônio para tombamento em 1938, Meira (2008: 238) relatou que o critério de escolha seria o histórico, sendo que na zona missioneira "o valor de arte se sobrepõe ao alto valor histórico". Talvez, o mais correto ao posicionar as Ruínas no tombamento seria perceber que por um lado estas foram "protegidas como exemplo de um ato de dominação brasileira sobre uma cultura espanhola "invasora", e por outro como importante bem material, "reduzindo o patrimônio missioneiro apenas à sua herança concretizada nas ruínas e nas esculturas" (Meira, 2008: 243-244).

No tocante à prática política e atuação institucional é de se perceber que isso passa pela legitimação das ruínas diante da comunidade local e regional. A relação entre território, produção cultural e instituições está diretamente relacionada com o processo social de negociação (assimilação e rejeição) desse patrimônio como produto cultural legítimo do território. O papel dessa política cultural parece ser oportuno na construção contemporânea da região das Missões.

Quais as implicações da política empreendida para a região? O contexto estabelecido 
reafirma as diferentes formas de valorização dos bens culturais. A política de valorização do patrimônio reconfigurou o uso e a significação desses elementos nas práticas sociais e culturais da população local e regional. Como sugere Bauer (2007: 11), houve um processo de realocação simbólica "de imagens de culto para objetos museológicos”. A religiosidade em torno desses objetos foi se tornando cada vez mais escassa e os laços de pertencimento "foram sendo progressivamente alterados, até que o sustentáculo material que dava suporte à devoção se tornou um lugar para os milhares de visitantes que se deslocam para ver as ruínas de São Miguel”.

Ao que parece, este relato evidencia a dimensão simbólica das políticas culturais que procuram transformar a ordem social no campo simbólico. A articulação entre passado e presente no campo da cultura reafirma os processos de rupturas e continuidades que são, muitas vezes, impulsionados por ações políticas empreendidas pelos governos e que se materializam, especialmente, nas práticas estabelecidas pelas instituições culturais. No caso da região das Missões, Bauer (2007: 10) atesta que "o que torna este aspecto ainda mais interessante é o fato de que esses relatos mantêm-se vivos na comunidade até hoje”.

Entretanto, há um segundo grande momento da atuação do governo federal, ainda sob a tutela do patrimônio histórico e artístico, na região das Missões. Trata-se da década de 70 e da situação política e econômica vivida no Brasil. Da euforia pelo "milagre econômico" até a derrota nas eleições de 1974 o governo militar, especialmente nos períodos de Ernesto Geisel (1974-1979) e João Figueiredo (1979-1985), sofreu uma crise de legitimidade que exigiu a contrapartida da criação de políticas públicas abrangentes e eficazes. Nesse contexto se insere a experiência do Centro Nacional de Referência Cultural (CNRC), "embrião da nova política de preservação cultural do Estado" (Falcão, 1984: 31). O Centro foi criado em 1975 por Aloísio Magalhães e trazia na sua concepção o propósito de rever as relações entre Estado e cultura, especialmente com as mudanças no conceito de patrimônio cultural, a abertura da cultura para as representações populares e a descentralização das políticas culturais. 
Na sequência das ações políticas houve a fusão entre o CNRC e o Instituto do Patrimônio Histórico e Artístico Nacional (IPHAN). Com isso, o IPHAN passa a ser visto dentro de uma política de perspectiva empresarial e economicamente integrada no contexto dos brasileiros e, ao que se percebe, inserido numa ampliação e reconfiguração da presença pública na produção cultural. Como indica Falcão (1984) a cultura passa a ter uma noção enquanto processo, especialmente processo histórico de continuidade e heterogeneidade (nação geográfica, étnica e tecnologicamente diversa e contraditória).

Quanto ao patrimônio material, o trabalho desenvolvido pelo IPHAN derivou de uma postura patrimonial voltada para a restauração de monumentos de "pedra e cal" e de obras de arte do passado (Miceli, 1984). Vale dizer, uma área da produção cultural na qual o mercado - muito interessado nos meios de comunicação de massa no contexto urbano-industrial - não atuava e que fazia do Estado a mão visível de fomento e manutenção. Aliás, é nesse contexto que se estabelecem as bases para o Plano Nacional de Cultura (PNC) de 1975. O PNC procurou enfocar a preservação dos bens de valor cultural, numa alusão ao que era autêntico em detrimento ao que era produto da indústria cultural. Assim, as instituições culturais do Estado passaram a atuar na cultura "legítima", no patrimônio histórico e artístico, e na cultura das classes populares, numa alusão ao folclore. Houve uma recusa intencional às atividades culturais vigentes na economia de mercado e, desta forma, "em lugar de carregar nas tintas do 'nacional', do legado 'comum' e 'brasileiro', os teóricos da gestão Portella valorizam o traço 'regional' e 'local', sede do que é ‘autêntico' e 'nosso'” (Miceli, 1984: 108).

Mas a questão do patrimônio material também respondia por outra preocupação política: o desenvolvimento urbano. Entre a urbanização acelerada e o abandono de algumas cidades estava o patrimônio cultural. Portanto, era preciso uma revalidação dos patrimônios históricos regionais em busca de um sincretismo nacional. Uma das soluções foi associar essa atividade com o investimento em turismo cultural, mas sem 
experiência na área a saída do governo foi pedir apoio à UNESCO (Calabre, 2009: 83). Desta forma, o governo planejou o desenvolvimento com a articulação entre o patrimônio, a população local e regional e as atividades econômicas possíveis de serem criadas e ampliadas a partir do turismo cultural.

Eis, então, o segundo elemento no escopo das políticas culturais que atuaram diretamente na região das Missões do Rio Grande do Sul. A conjuntura que marca a política nacional na cultura vai incidir na região com algumas particularidades.

Em 1979 as Missões viraram notícia a partir da elaboração de um projeto desenvolvido pelo Governo do Estado do Rio Grande do Sul e da prefeitura de Santo Ângelo. A intenção era apontar as diretrizes para o desenvolvimento de São Miguel (distrito de Santo Ângelo), com o apoio do IPHAN. Naquele mesmo ano ocorre uma reunião entre técnicos da Argentina, Paraguai e Brasil em Assunção que definem várias ações, com destaque para o pedido de apoio à UNESCO e a criação de subcomitês - especialmente do turismo - para articular ações entre as "três regiões" missioneiras.

O ano de 1980 parece consolidar o plano estabelecido anteriormente. Há duas medidas consideradas: disciplinar o uso do solo para proteger a ambientação das ruínas; restaurar a estrutura das ruínas com risco de desabamento. Primeiramente nota-se uma clara posição institucional para a regulação das práticas sociais em torno do patrimônio e, no segundo ponto, uma ação prática, organizativa no próprio patrimônio. Mas se em 79 já era possível perceber a articulação política-institucional além do território das Missões, foi no início dos anos 80 que essas articulações foram efetivadas dentro da região, com a visita do professor Roberto Di Stefano, técnico da UNESCO². Pode-se dizer que do convite feito pela secretária de patrimônio até a vinda e consolidação dos trabalhos do professor Di Stefano as ruínas foram inseridas em três diretrizes fundamentais.

A primeira diretriz está contida dentro da própria preocupação técnica com a

${ }^{2} \mathrm{O}$ professor italiano Roberto Di Stefano era engenheiro civil e presidente do comitê italiano do ICOMOS (Conselho Internacional de Monumentos e Sítios). 
restauração daquele patrimônio. Por um lado a visão de que era preciso desmontar e remontar, como havia ocorrido na década de 30. Por outro, na visão defendida pelo professor, era preciso aplicar técnicas mais modernas de restauro que não agredissem demasiadamente a estrutura das ruínas (Instituto do Patrimônio Histórico e Artístico Nacional, 1980).

Tem-se aqui a função normativa e, até mesmo, organizativa da UNESCO enquanto instituição cultural. Como disse o IPHAN à época, depois de vários estudos foi realizada uma "restauração rigorosamente científica" nas ruínas. Em oposição a desmontagem utilizaram-se técnicas de "embrechamento" e de amarras de aço.

A segunda diretriz está focada na dimensão econômica das ruínas. Isto estaria atrelado a consolidação turística desse patrimônio. No entanto, a UNESCO reafirma a necessidade de se ter um plano estruturado para a divulgação e reconhecimento das ruínas. Disse o professor Di Stefano que "a pouca divulgação dada às reduções jesuíticas impedem que elas sejam melhor conhecidas, principalmente no exterior”. Ele não hesitava em reconhecer nas ruínas "a mesma importância de outras ruínas célebres, como a Acrópole, o Coliseu e outras” (apud Serviço Nacional de Teatro e o Serviço do Patrimônio Histórico e Artístico Nacional, 1980: 09).

O apoio explícito de Di Stefano, evidentemente da própria UNESCO, vai ao encontro da política federal, estadual e, naquele momento, até municipal de desenvolvimento. Em 1982 a União sinaliza a liberação de recursos em duas frentes: nas obras de restauração e no planejamento global da redução. Buscava-se, assim, a criação de um parque turístico dentro de São Miguel das Missões.

Se as primeiras diretrizes demonstram a dupla materialidade empreendida pela política cultural do patrimônio, é na terceira que será possível perceber a ação prática no contexto simbólico das Missões jesuíticas-guaranis. Resumidamente é viável pensar que as ruínas precisavam ser legitimadas pelas práticas sociais da população local e regional. Outrora a construção era vista como uma obra jesuítica espanhola. Naquele 
momento o patrimônio era considerado missioneiro e reconhecido como "patrimônio cultural do país”. Retoma-se assim o plano de diretrizes para o desenvolvimento de São Miguel, a cargo da prefeitura de Santo Ângelo. Era preciso ter em conta os benefícios sociais e econômicos do projeto, mas de nada adiantaria se ele não estivesse perfeitamente integrado na dinâmica social da população (Serviço Nacional de Teatro e o Serviço do Patrimônio Histórico e Artístico Nacional, 1982).

A preocupação em tornar o patrimônio uma prática social reconhecida e apropriada pela população local e regional era um dos pontos nevrálgicos da política cultural multidimensional empreendida pelos governos e instituições parceiras. Nesse contexto, não se pode esquecer a dimensão da política internacional, pois se queria estabelecer uma relação entre Brasil e as Nações Unidas, via UNESCO.

Todo o trabalho desenvolvido enquanto política cultural nas ruínas de São Miguel vai ser consolidado em 1983. No dia 06 de dezembro daquele ano, em Florença, Itália, a plenária anual do Comitê do Patrimônio Mundial da UNESCO reconhece as ruínas de São Miguel das Missões como Patrimônio Mundial da Humanidade. O Secretário da Cultura do Ministério da Educação e Cultura, Marcos Vilaça, presente no evento, faz questão de dizer que a outorga enquanto patrimônio da humanidade era o “reconhecimento internacional à política brasileira de preservação e valorização dos bens históricos e culturais do País" (Serviço do Patrimônio Histórico e Artístico Nacional, 1983: 02). Pretensiosamente, pode-se dizer que foi a legitimação que faltava às ruínas como um patrimônio cultural verdadeiramente gaúcho e nacional. Mais um recurso para reconhecimento e apropriação cultural das Missões na dinâmica social local e regional, já que essa integração era considerada uma preocupação pontual.

A configuração das políticas culturais focadas no patrimônio apresenta uma gama de práticas e instituições que conectam a produção cultural no território. De maneira muito objetiva é viável perceber a relação entre fixos e fluxos na região por meio de instituições que relacionaram, em graus variados, o material e o simbólico na produção 
da cultura. Com tais instituições nota-se uma variação de atribuições dentro do contexto social estabelecido no país e, especialmente, na região. Os exemplos a seguir concorrem nessa mesma ordem.

\section{b) Estado e música}

A noção de música regional missioneira está centrada na apropriação ao passado das Missões (Pommer, 2008). Há, objetivamente, o critério da especificidade de ser missioneira mais do que ter alguma aproximação com a musicalidade do período reducional. Considerada, assim, por alguns autores a pedra de toque da invenção de uma cultura missioneira atrelada à região. No entanto, a consideração da música dentro de uma perspectiva forjada e deslocada de um passado sem continuidade ignora o contexto fundamental que permeia a noção de produção cultural, vista no início desse estudo. Trata-se de ver a música como um dos elementos culturais recursivos na dinâmica social, inserido dentro de um contexto estruturado e estabelecido num jogo de relações entre diferentes atores sociais. Nos termos que aqui se referem a produção cultural, o que proporciona à música missioneira seu caráter específico não é o fato desta ter sido estabelecida no período reducional, nem tem nada a ver com até que ponto ela retém com exatidão os acontecimentos daquele período, mas sim, ter a conexão com o território e com a cultura no espaço multidimensional e de múltiplas apropriações. Giddens (1997) dirá que os “materiais antigos" serão usados pelas instituições modernas para fins modernos (legitimidade para os sistemas de poder).

Dito isso, é preciso compreender o contexto em que se estabelece essa música regional. A formação da música missioneira partiu da década de 60 e esteve atrelada à denúncia e protesto. Noel Borges do Canto Fabrício da Silva (1941-1998) é considerado o principal criador e divulgador dessa música no contexto regional. Noel Guarany, como ficou conhecido, após desavenças no Exército Brasileiro resolveu percorrer a América do Sul (Bolívia, Paraguai, Uruguai, Argentina e centro-oeste do Brasil), para ampliar o escopo de possibilidades artísticas. Ele qualificou sua atividade como música de 
pesquisa e se negava em participar dos festivais de música (Pommer, 2009). Noel Guarany, juntamente com Cenair Maicá (1947-1989), Jaime Caetano Braun (19241999) e Pedro Ortaça (1942-) são considerados os precursores da música missioneira. O significado fundamental da música era protestar "contra certas atitudes políticas, culturais e econômicas da época, fortalecendo a música como tendência de singularização regional” (Pommer, 2008: 177).

A questão que enseja o Estado na relação com a produção musical missioneira está pautada por duas situações. A primeira é o contexto em que surgiu esse tipo de música. O período era marcado pela repressão social diante da ditadura militar. O uso recursivo de elementos jesuíticos-missioneiros são reposicionados, diferentemente do patrimônio material, como mecanismo de protesto e inconformismo. Sabe-se que Noel Guarany, talvez o mais engajado de todos os já citados, atuou em movimentos populares exigindo a liberdade democrática, participando de movimentos estudantis e de greve de bancários no RS. Em 1977, por exemplo, foi convidado a participar de um evento no centro do país juntamente com Edu Lobo, Chico Buarque, entre outros artistas da MPB. O show acabou cancelado pelo governo por seu conteúdo crítico, mas Noel Guarany passou a ter expressão em jornais do centro do país, e por conta disso divulgou São Luiz Gonzaga, que começava a ficar conhecida como capital da música missioneira (Pommer, 2009: 176-177).

Assim, diferentemente do ocorrido no campo do patrimônio, a música e sua existência dinâmica e fluída na qual se efetiva na vida social, apresenta um jogo de relações e intenções recursivas diferente da prática institucional empreendida pelo Governo Federal à época. A música "escapa” da ação institucional, mesmo com elementos de repreensão e repressão aplicadas pelos governos. O reconhecimento e a legitimação partem do cotidiano, dos usos e apropriações, mais do que da legitimação institucional do Estado.

Já a segunda situação responde por uma ação do Estado efetivada recentemente: o 
reconhecimento de São Luiz Gonzaga como capital da música missioneira. O que confere esse reconhecimento está, em primeiro lugar, baseado na origem dos quatro expoentes da música missioneira. Todos são naturais de São Luiz Gonzaga (mesmo que Bossoroca, por exemplo, como distrito de São Luiz tenha sido a terra natal de Noel Guarany). O segundo ponto, já comentado, era a ação desses músicos referenciando sempre São Luiz Gonzaga como seus locais de origem. Ainda, não se pode negar que a população que tinha contato com essa produção cultural já fazia referência a São Luiz Gonzaga como terra da música missioneira.

No entanto, esse reconhecimento institucionalizado só foi realizado em 2012, quando aprovada a Lei Estadual $\mathrm{n}^{0} 14.123 / 2012$, projeto de lei encaminhado pelo Deputado Estadual Diógenes Basegio (PDT), que no texto de justificativa argumenta:

Nesse contexto, um dos episódios mais interessantes da cultura brasileira, o resgate e a definição da identidade missioneira, teve São Luiz Gonzaga como epicentro. Não só pela sua importância, mas pela forma como ocorreu, espontânea e totalmente à margem dos âmbitos letrados, tendo como artífices artistas populares com sólida cultura (Basegio, 2012: 01).

Isso, no entender do estudo, talvez seja reflexo do furor da proposição em reconhecer o município mais do que propriamente a música regional. Na sequência o Deputado enfatiza os "quatro troncos missioneiros" e a história jesuítica-guarani, para, por fim, destacar esses episódios como fundamentais na criação de "uma nova identidade da cultura musical gaúcha”, uma “verdadeira música missioneira” (Basegio, 2012: 02).

Nesse sentido, o que se percebe é que se por um lado a produção cultural efetivamente se realiza num jogo de relações de atores sociais com diferentes intenções recursivas, por outro essas ações nem sempre são, e precisam ser, institucionalizadas para serem reconhecidas e legitimadas no contexto social. A política empreendida no reconhecimento da música parece surgir mais como uma proposta de localizar territorialmente do que legitimar sua prática. Afinal, esta já foi reconhecida desde a década de 6o. A atribuição dessa "política cultural” se resume na normatização de uma 
prática social.

\section{c) Estado e outras atividades culturais}

Outra iniciativa do Estado, especificamente do Governo Federal, é interessante dentro do contexto da região das Missões. Trata-se do programa do "Ponto de Memória", que está associado ao Plano Nacional de Cultura dentro dos programas Cultura Viva e Mais Cultura. O primeiro procura estimular e fortalecer a criação e gestão cultural e o segundo busca ampliar as ações de produção e consumo cultural, relacionado com os eixos "cultura e cidades", "cultura e cidadania" e "cultura e economia". Os Pontos de Memória estão associados aos dois programas e estão contidos no eixo "cultura e cidades", especialmente por buscar qualificar o ambiente social das cidades e democratizar o acesso aos equipamentos culturais. Assim, o programa atende aos diferentes grupos sociais que não tiveram suas histórias, memórias e patrimônios narrados e expostos em museus.

As diretrizes do programa posicionam a política pública focada no direito à memória em diálogo e com a participação de diferentes grupos e movimentos sociais. Fala-se nos indígenas, quilombolas, grupos das culturas populares, urbanas, rurais, de fronteira, artistas e grupos artísticos independentes, além de "segmentos populacionais etários específicos, de gênero, e/ou que requerem maior reconhecimento de seus direitos humanos, sociais e culturais” (Instituto Brasileiro de Museus, 2014). Desta forma, essa proposta é perfeitamente reconhecível dentro das políticas de democracia cultural empreendidas no contexto atual do Brasil.

Em São Miguel das Missões uma atividade comunitária foi contemplada com o prêmio Ponto de Memória em 2011, projeto denominado Ponto de Memória Missioneira. Mas a elucidação desse caso é interessante pela atuação do Estado num espaço já existente de produção cultural, especialmente no campo identitário e de pertencimento. O processo de apropriação e de reconhecimento das Ruínas de São Miguel por parte da comunidade local e regional, como visto anteriormente, foi sempre catalisado por ações 
do Estado. É perfeitamente possível imaginar que nessa negociação nem sempre houve uma aceitação das práticas empreendidas no território. No estudo de Silva (2009) é possível perceber a configuração dos bens culturais no cotidiano dos moradores de São Miguel como um "patrimônio a contragosto".

As ruínas se transformam num espetáculo perturbador e revelador de contradições sociais. O município passa a abrigar um grande campo de tensões entre seres humanos, objetos qualificados e espaços socialmente construídos. De fora das reuniões que definem os rumos dados ao lugar, os miguelinos passam então a reagir veladamente para terem seu bem de volta (Silva, 2009: 93).

O pesquisador expõe a exclusão dos munícipes nas decisões sobre temas relacionados ao patrimônio de São Miguel e relata a atuação das instituições nacionais e internacionais que em inúmeras ações deixaram de lado qualquer atitude de interação ou relacionamento com a população local. E sentencia dizendo que "mesmo que seja formalmente aberto a todos, nem todos poderão provar dos conteúdos e valores atribuídos ao espaço sacralizado" (Silva, 2009: 93).

Realmente, tais ações são legítimas dentro do campo da produção cultural. Em se tratando de um contexto histórico tão complexo e de uma atuação diversa de diferentes agentes e instituições culturais ao logo do tempo, não é estranho a rejeição das práticas culturais empreendidas pelas instituições do setor. No entanto, o caso do Ponto de Memória revela uma prática comunitária na qual a população local aceita aquela produção cultural como intrínseca a sua trajetória pessoal e coletiva. Assim, para entender a relação entre Estado e cultura, no caso em tela especialmente, é preciso compreender a ação comunitária.

Tudo começou, conforme relata Vivian (2012), com a organização da "Exposição da Cultura Missioneira” realizada pelo senhor Valter Braga no início dos anos 2000. A exposição continha inúmeros objetos do período reducional, capitaneados por Braga e pelos demais moradores de São Miguel. Um fato marcante elucida a presença desses 
objetos no cotidiano da população: em 1990 foram realizadas obras de mobilidade urbana no município, ocasião na qual foram abertas e pavimentadas diversas ruas na cidade. Aquele evento foi acompanhado pelos moradores que seguiam as máquinas à procura de objetos do período jesuítico-guarani. Nota-se, portanto, a construção de um imaginário que acabava apropriando elementos materiais no dia a dia da população local.

Mas o senhor Braga quis dar uma dimensão maior para os objetos de sua posse e aos demais doados pela população. Criou e trabalhou para a consolidação da exposição dentro de uma área de sua propriedade (próximo às ruínas). A partir de boas relações estabelecidas localmente, o empreendedor conseguiu, aos poucos, a adesão de outros moradores, não só para a formação do acervo, mas para organização do local.

Estabeleceu-se, assim, uma relação com outros agentes culturais capazes de auxiliar e dar o apoio necessário à legitimação daquele espaço como ponto de memória coletiva da comunidade local. Desta forma, em contraposição ao espaço institucionalizado das ruínas, o espaço criado tornou-se uma oportunidade para que os habitantes de São Miguel “dispusessem de meios legítimos para atuar na 'arena patrimonial', descrevendo e divulgando suas histórias e patrimônios a partir de seus próprios termos" (Vivian, 2012: 1204).

A transformação em Ponto de Memória vai inserir a presença de uma instituição cultural, vinculada ao Estado, em diálogo com a comunidade local e dentro de uma política cultural preocupada com a participação de diferentes grupos no universo da memória coletiva. O órgão, que é responsável pela Política Nacional de Museus (PNM) e pela melhoria dos serviços do setor (visitação, arrecadação, fomento e preservação de acervos), vai atuar como mediador entre as práticas comunitárias e a política cultural.

Portanto, a configuração desse processo vai reafirmar o entendimento da produção cultural e das relações variadas estabelecidas entre a população do território, os agentes e as instituições. A política cultural e a atuação institucional vão ao encontro da 
legitimação dada pela comunidade ao conjunto de artefatos e objetos reconhecidos como bens culturais. Desta forma, não se pode desconsiderar o papel mediador que envolve as políticas culturais e, mais especificamente, as instituições.

\section{6. À guisa de conclusão: atribuições das instituições culturais}

Resumidamente, as instituições culturais podem ser compreendidas como uma estrutura social composta por regras, convenções e práticas regulares que conformam determinados circuitos e domínios culturais; atuando na normatização, regulação e cognição de práticas e comportamentos sociais; e estabelecidas em diferentes formas, posições e finalidades na produção cultural.

Nessa perspectiva, de forma conclusiva, faz-se a sistematização das atribuições das instituições culturais dentro da produção cultural. Parte-se de duas dimensões. A primeira associa as características fundamentais das instituições composta por três aspectos - regulação, normatização e cognição. A segunda volta-se para as peculiaridades das instituições culturais oriundas dos fatores que mencionam agentes, estruturas e relações estabelecidas na produção cultural, especialmente os aspectos de gestão e mediação. Assim, apresentam-se cinco atribuições como constitutivas das instituições culturais:

Regulação - de modo geral é possível visualizar uma perspectiva de agir sobre comportamentos e ações em diferentes momentos da produção cultural. Assim, o dispositivo regulatório está contido nas pretensões de "assegurar as condições", "fiscalizar" estruturas e atividades e na emissão de pareceres em atividades realizadas em domínios culturais como o patrimônio arquitetônico. Há uma intenção de estabelecer regras e monitorar as práticas de acordo com o que foi estabelecido.

Normatização - sugere um conjunto de princípios que procuram ordenar, estabelecer e recomendar como as práticas e os comportamentos devem ser realizados. Nesse sentido, as instituições culturais do Estado propõem medidas de instrução, apoio técnico e participação em determinadas áreas com o objetivo de prescrever normas, 
regras e demais dispositivos legais que devam ser considerados.

Cognição - as instituições culturais atuam na constituição da realidade social da produção cultural e da própria condição do Estado nesse processo. Assim, quando se apoiam iniciativas culturais no contexto territorial do Estado (União, Estados e municípios) há uma ênfase em constituir, manter e difundir significados dentro de um quadro de referências.

Gestão - a atribuição de organizar e gerir determinados aspectos ou todo o circuito cultural. Aspectos que consideram as institucionalidades como instâncias organizativas da produção cultural dentro de um ou vários domínios. Na gestão é estabelecida a autonomia em realizar atividades como agente cultural. Nessa ordem, há ações de organização e gestão da produção, circulação e, também, do consumo cultural.

Mediação - atribuição dada às instituições culturais com capacidade de articular diferentes instâncias, objetos e agentes sociais. Por exemplo, políticas culturais e públicos ou criador cultural e patrocinadores, etc. A configuração mediadora depende da capacidade de articulação e relacionamento estabelecido dentro de determinado circuito e domínio cultural. No entanto, confere-se às instituições culturais uma força em potência para articulação, para determinada política cultural atingir o seu públicoalvo as instituições podem mediar e estabelecer essa conexão. No Brasil, o Instituto Brasileiro de Museus (IBRAM) realiza essa atividade quando, por exemplo, faz a conexão com as políticas culturais do governo federal e os públicos prioritários dessas políticas, como os índios, quilombolas, etc. nos apoios aos "Pontos de Memória".

Tais atribuições devem ser vistas como possibilidade e, ao mesmo tempo, não isoladas como única atribuição. O grau de realização evidenciará que podem ser atribuídas tais designações, no entanto, não necessariamente estas são efetivadas nas práticas sociais estabelecidas em determinado momento e domínio da produção cultural. Mesmo assim, a compreensão de tais atribuições contribui significativamente para as pesquisas e as práticas culturais, como as políticas culturais. 


\section{Referências Bibliográficas}

Basegio, Diógenes (2012) Justificativa Projeto de Lei 172/2012. Porto Alegre: Assembleia Legislativa. http://www.al.rs.gov.br/legislativo/ProjetosdeLei.aspx (consultado em 16 de Fevereiro de 2014).

Bauer, Leticia (2007) "O arquiteto e o zelador: patrimônio cultural, História e Memória”, Nuevo Mundo Mundos Nuevos, [Online], Debates, pp. 1-18. http://nuevomundo.revues.org/3807 (consultado em 16 de Fevereiro de 2014).

Brunner, José Joaquín (1985) La cultura como objeto de políticas. Santiago, Chile: FLACSO.

(1987) "Políticas culturales y democracia: hacia una teoría de las oportunidades”, in Canclini, Néstor García (ed.) Políticas culturales en América Latina. México: Editorial Grijalbo, pp. 175-203.

Calabre, Lia (2009) Políticas Culturais no Brasil: dos anos 1930 ao século XXI. Rio de. Janeiro: FGV.

Canclini, Néstor García (1979) A produção simbólica: teoria e metodologia em sociologia da arte. Rio de Janeiro: Civilização Brasileira. (1983) As culturas populares no capitalismo. São Paulo:

Editora Brasiliense.

(1987) Políticas culturales en América Latina. México:

Editorial Grijalbo.

Dias, Reinaldo (2010) Introdução à Sociologia. São Paulo: Pearson.

Falção, Joaquim Arruda (1984) "Política cultural e democracia: a preservação do patrimônio histórico e artístico nacional”, in Miceli, Sérgio (Org.) Estado e cultura no Brasil. São Paulo: Difusão Editorial, pp. 21-39.

Giddens, Anthony (2007) As consequências da modernidade. São Paulo: EDUNESP. 
Hall, Stuart (1997) “A centralidade da cultura: notas sobre as revoluções culturais do nosso tempo". Cultura, Mídia e Educação - Educação \& Realidade, Porto Alegre, v. 22, n 2, jul./dez, pp. 15-46.

Horkheimer, Max \& Adorno, Theodor (2000) “A indústria cultural: o iluminismo como mistificação de massas”, in Adorno, Theodor et alii Teoria da cultura de massa. São Paulo: Paz e Terra, pp. 169-214.

Instituto Brasileiro de Museus (2014) O IBRAM nas Missões. Entrevista eletrônica. Mensagem recebida por <diego.luiz@museus.gov.br> em 12 de agosto de 2014.

Instituto do Patrimônio Histórico e Artístico Nacional (1980) Boletim do IPHAN/Programa de Cidades Históricas. n.05, mar./abr., Rio de Janeiro.

Meira, Ana Lúcia G (2008) Patrimônio Histórico e Artístico Nacional no Rio Grande do Sul no século $X X$ : atribuições de valores e critérios de intervenção. Tese (Programa de Pós-graduação em Planejamento Urbano e Regional) - Universidade Federal do Rio Grande do Sul, Porto Alegre.

Miceli, Sérgio (1984) “Teoria e prática da política cultural oficial no Brasil”, in Miceli, Sérgio (Org.) Estado e cultura no Brasil. São Paulo: Difusão Editorial, pp. 97-112.

Pommer, Roselene (2008) Missioneirismo: a produção de uma identidade regional. Tese (Programa de Pós-graduação em História) - Universidade do Vale do Rio dos Sinos, Rio Grande do Sul, Porto Alegre.

Reis, Paula Félix (2011) Estado e Políticas Culturais. (Anais do II Seminário Internacional de Políticas Culturais, Rio de Janeiro, 21-23 de setembro de 2011), http://culturadigital.br/politicaculturalcasaderuibarbosa/2011/11/o6/artigos-do-iiseminario-internacional-de-politicas-culturais/ (consultado em 16 de Fevereiro de 2014).

Secchi, Leonardo (2013) Políticas Públicas: conceitos, esquemas de análise, casos práticos. São Paulo: Cengage Learning. 
Serviço do Patrimônio Histórico e Artístico Nacional (1983) Boletim do SPHAN/próMemória, n.o7, jul./ago, Rio de Janeiro.

Silva, Willians Fausto (2000) Patrimônio a contragosto: A presença de bens culturais na vida cotidiana de São Miguel das Missões/RS. Dissertação (Mestrado em Museologia e Patrimônio) - Universidade Federal do Estado do Rio de Janeiro, Rio de Janeiro.

Scott, W. Richard (2008) Institutions and Organizations: ideas and interests. Los Angeles: Sage publications.

Thompson, John B (1995) Ideologia e cultura moderna: teoria social crítica na era dos meios de comunicação de massa. São Paulo: Editora Vozes.

UNESCO (2009) Marco de Estadísticas culturales (MEC) 2009. Montreal: UNESCOUIS.

Vivian, Diego (2012) Ponto de memória missioneira: iniciativas comunitárias e populares de preservação e promoção do patrimônio cultural em São Miguel das Missões (RS). (Anais do XI Encontro Estadual de História, Rio Grande, 23-27 de julho de 2012), Rio Grande: ANPUHRS, pp. 1199-1210.

Willians, Raymond (1981) Sociología de la cultura. Barcelona: Ediciones Paidós Ibérica.

Marcela Guimarães e Silva: Doutora em extensão rural pela Universidade Federal de Santa Maria (UFSM). Professora Adjunta do curso de relações públicas - ênfase em produção cultural da Universidade Federal do Pampa - Unipampa, campus São Borja/RS, Brasil. Coordenadora do grupo pesquisa: Processos e Práticas nas Atividades Criativas e Culturais (CNPq). Integrante do Observatório Missioneiro de Atividades Criativas e Culturais (OmiCult). marcelasilva@unipampa.edu.br

Tiago Costa Martins: Doutor em desenvolvimento regional pela Universidade de Santa Cruz do Sul (UNISC). Professor Assistente do curso de relações públicas - ênfase em produção cultural da Universidade Federal do Pampa - Unipampa, campus São Borja/RS, Brasil. Coordenador do Projeto de Pesquisa em Política e Economia da Cultura na região das Missões (CNPq/Ministério da Cultura). Pesquisador do grupo pesquisa: Processos e Práticas nas Atividades Criativas e Culturais (CNPq). Integrante do Observatório Missioneiro de Atividades Criativas e Culturais (OmiCult). tiagomartins@unipampa.edu.br 